\title{
Prejunctional Regulation by Endogenous and Exogenous Acetylcholine of Adrenergic Nerve Function in Isolated Canine Mesenteric Arteries
}

\author{
Jian-Xin Zhang, Tomio Okamura, and Noboru Toda
}

\begin{abstract}
Transmural electrical stimulation $(5-30 \mathrm{~Hz})$ produced a frequency-dependent increase in the perfusion pressure of isolated, perfused dog mesenteric artery segments without the endothelium, which was abolished by prazosin or tetrodotoxin. Physostigmine inhibited the pressor response to transmural electrical stimulation, whereas atropine potentiated the response. Treatment with acetylcholine $\left(10^{-6}\right.$ and $10^{-5}$ M) dose-dependently inhibited the response to electrical nerve stimulation. The effect was reversed by the addition of atropine and AF-DX 116 at a concentration $\left(10^{-7} \mathrm{M}\right)$ that selectively blocked the $\mathrm{M}_{2}$ receptor subtype, but not by pirenzepine or 4-DAMP. Acetylcholine did not alter the pressure raised by norepinephrine in perfused arterial segments nor the contraction caused by exogenous norepinephrine in the artery strips. ${ }^{3} \mathbf{H}$-overflow evoked by transmural electrical stimulation from tissues prelabeled with $\left[{ }^{3} \mathrm{H}\right]$ norepinephrine was decreased by acetylcholine $\left(10^{-6} \mathrm{M}\right)$ in the superfused dog mesenteric arterial strips. It is concluded that acetylcholine inhibits adrenergic neurogenic contractions by interfering with the release of norepinephrine, which possibly results from activation of the prejunctional $\mathbf{M}_{2}$ receptor subtype. (Hypertens Res 1997; 20: 119-125)
\end{abstract}

Key Words: acetylcholine, muscarine $\mathrm{M}_{2}$ receptor, adrenergic nerve stimulation, prejunctional inhibition, mesenteric artery

Although vasomotor nerves are mainly adrenergic, there are some arteries innervated by cholinergic vasodilator nerves (1). Previous studies have shown that stimulation of muscarinic receptors located on noradrenergic nerve terminals by exogenously applied acetylcholine (ACh) inhibits the release of transmitter, as determined by measuring the release of incorporated ${ }^{3} \mathrm{H}$-norepinephrine during transmural nerve stimulation (2-4). At least three different subtypes of the muscarinic receptor have been pharmacologically characterized. Muscarinic receptors that show high affinity for the antagonist pirenzepine are referred to as $\mathbf{M}_{1}$ subtypes (5-7), whereas those with low affinity for this agent are classified as $\mathrm{M}_{2}$ and $\mathrm{M}_{3}$ subtypes $(6,7) . \mathrm{M}_{2}$ receptor subtypes, as compared with $\mathrm{M}_{3}$ subtypes, display a high affinity for AF-DX 116 (11-[(2-[(diethyl-amino) methyl]1-piperidinyl) acetyl]-5, 11-dihydro-6H-pyrido-[2, 3b] [1, 4]-benzodiazepine-6-one) (6). The $\mathrm{M}_{3}$ receptors are blocked by lower concentrations of 4DAMP (4-diphenylacetoxy- $N$-methyl-piperidine methiodide) (8), as compared with $\mathbf{M}_{2}$ receptors. Modulatory prejunctional muscarinic receptors are present on neurons liberating various neurotransmitters, and there is evidence that the subtypes of muscarinic receptors involved at these sites are not identical for all neurons. The prejunctional musca- rinic inhibitory heteroreceptors present on sympathetic nerves in different tissues also vary as to their subtype; those in the heart (9-11) and rabbit iris (12) appear to be muscarine $\mathrm{M}_{2}$ receptors, whereas those in the rabbit vas deferens are of the $\mathrm{M}_{1}$ subtype (13). Nevertheless, little is known about the subtype of these receptors present on adrenergic nerve endings modulating norepinephrine release in dog mesenteric arteries.

Aims of the present work were to characterize the subtype of muscarinic receptors involved in the inhibitory effect of acetylcholine on the pressor response to electrical nerve stimulation in perfused dog mesenteric arterial segments and to determine whether endogenous $\mathrm{ACh}$ from cholinergic nerve interferes with the response to adrenergic nerve stimulation. For this purpose, antagonists such as atropine (non-specific), pirenzepine ( $\mathbf{M}_{1}$ antagonist) (5), AF-DX $116\left(\mathrm{M}_{2}\right.$ antagonist) (6), and 4-DAMP $\left(\mathrm{M}_{3}\right.$ antagonist) (13) and the agonist $\mathrm{ACh}$ were used.

\section{Materials and Methods}

Studies on Mechanical Response

The Animal Care and Use Committee at Shiga University of Medical Science approved the use of dog

From the Department of Pharmacology, Shiga University of Medical Science, Seta, Japan.

Address for Reprints: Noboru Toda, M.D., the Department of Pharmacology, Shiga University of Medical Science, Seta, Ohtsu 520-21, Japan.

Received December 12, 1996; accepted in revised form April 4, 1997. 
blood vessels in this study. Mongrel dogs of either sex, weighing 7 to $13 \mathrm{~kg}$, were anesthetized with intravenous injections of sodium thiopental (30 $\mathrm{mg} / \mathrm{kg}$ ) and killed by bleeding from the carotid arteries. Proximal portions of the superior mesenteric artery of 0.9 to $5.0 \mathrm{~mm}$ outside diameter were isolated. The artery segments were placed in a bath of 40-ml capacity and perfused luminally with modified Ringer-Locke solution maintained at $37 \pm 0.3^{\circ} \mathrm{C}$ and aerated with a mixture of $95 \% \mathrm{O}_{2}$ and $5 \% \mathrm{CO}_{2}$ at a constant rate of $1 \mathrm{ml} / \mathrm{min}$ with a pressure of 40 to $50 \mathrm{mmHg}$ (4). Constituents of the solution were as follows (mM): $\mathrm{NaCl} 120, \mathrm{KCl} 5.5, \mathrm{CaCl}_{2} 2.2$, $\mathrm{MgCl}_{2}$ 1.0, $\mathrm{NaHCO}_{3} 25.0$, and dextrose 5.6. The $\mathrm{pH}$ of the solution was 7.36 to 7.43 . The perfusion pressure was measured via a pressure transducer (Nihon-Kohden Kogyo Co., Tokyo, Japan) placed upstream of the artery segment. Perfused segments were placed between a pair of stimulating electrodes made of platinum plate. The gap between the segment and the electrodes was wide enough to allow undisturbed contractions and yet sufficiently narrow enough to permit stimulation of intramural nerve terminals. Under resting conditions, electrical square pulses of supramaximal intensity were applied transmurally at frequencies of $5,10,20$, and $30 \mathrm{~Hz}$ for $40,20,10$, and $7 \mathrm{~s}$, respectively (total number of pulses, 200-210), every 10 to $15 \mathrm{~min}$ to stimulate perivascular nerves innervating the arterial wall. Transmural electrical stimulation was applied repeatedly until steady responses were obtained, and then the agents, such as acetylcholine (ACh), atropine, pirenzepine, AF-DX 116, and 4-DAMP, were directly applied to the bathing media. At the end of the experiment, tetrodotoxin was applied to determine whether the induced response was due to stimulation of perivascular nerves. In preliminary experiments, the stimulation-induced increase in perfusion pressure was observed to be steady for over $2 \mathrm{~h}$. The endothelium was removed by rubbing with cotton twine along with a polyethylene catheter inserted into the lumen of the segment. Successful removal of the endothelium was determined by abolishment of the depressor response induced by $10^{-6} \mathrm{M}$ ACh applied intraluminally.

Some of the mesenteric arteries (outside diameter 0.5 to $0.8 \mathrm{~mm}$ ) were cut into helical strips of approximately $20 \mathrm{~mm}$ long to evaluate the effect of ACh on responses to norepinephrine. The endothelium was removed by gently rubbing the intimal surface of the strip with a cotton ball. Removal of the endothelium was verified by abolishment of relaxation caused by $10^{-6} \mathrm{M}$ ACh. The strips were fixed vertically between hooks in a muscle bath of $20-\mathrm{ml}$ capacity containing the modified Ringer-Locke solution, which was maintained at $37 \pm 0.3^{\circ} \mathrm{C}$ and aerated with a mixture of $95 \% \mathrm{O}_{2}$ and $5 \% \mathrm{CO}_{2}$. Isometric mechanical responses were recorded on an ink-writing oscillograph. The resting tension was adjusted to $1.5 \mathrm{~g}$, which is optimal for inducing maximum contraction (14). Norepinephrine $\left(10^{-7}\right.$ to $10^{-5} \mathrm{M}$ ) was applied cumulatively to the bathing media to obtain the concentration-response curve.
${ }^{3} \mathrm{H}$-Overflow Study

Isotope experiments were carried out on helical strips of dog mesenteric arteries as described previously (15). The tissue was preincubated for $60 \mathrm{~min}$ at $37^{\circ} \mathrm{C}$ with $5 \times 10^{-7} \mathrm{M}\left[{ }^{3} \mathrm{H}\right]$ norepinephrine (specific activity, $56.9 \mathrm{Ci} / \mathrm{mmol}$ ). The tissue was then superfused with the modified Ringer-Locke solution containing cocaine $\left(3 \times 10^{-5} \mathrm{M}\right)$ and corticosterone $\left(4 \times 10^{-5} \mathrm{M}\right)$ at a rate of $1 \mathrm{ml} / \mathrm{min}$. The preincubated strips were stimulated electrically 5 times for $3 \mathrm{~min}$ at a frequency of $5 \mathrm{~Hz}$. Stimulation was applied after $126\left(\mathrm{~S}_{1}\right), 144\left(\mathrm{~S}_{2}\right), 162\left(\mathrm{~S}_{3}\right), 180\left(\mathrm{~S}_{4}\right)$, and $198 \mathrm{~min}\left(\mathrm{~S}_{5}\right)$ of superfusion. At the end of the superfusion, tritium counts in the superfusate collected each $3 \mathrm{~min}$ and in the tissues solubilized by toluene were measured. The stimulation-evoked ${ }^{3} \mathrm{H}-$ overflow of total tritium was calculated as percent of the tissue tritium content at the time of stimulation. ACh was added $12 \mathrm{~min}$ before $\mathrm{S}_{4}$. Effects of the drug on stimulation-evoked ${ }^{3} \mathrm{H}$-overflow were expressed as the ratio between the overflow evoked by $S_{4}$ or $S_{5}$ and that evoked by $S_{3}$. The ratios were compared with those obtained in the absence of treatment with the drug. ACh did not affect the spontaneous overflow of tritium.

\section{PERFUSED DOG MESENTERIC ARTERY (E-)}

Transmural stimulation, $20 \mathrm{~Hz}$

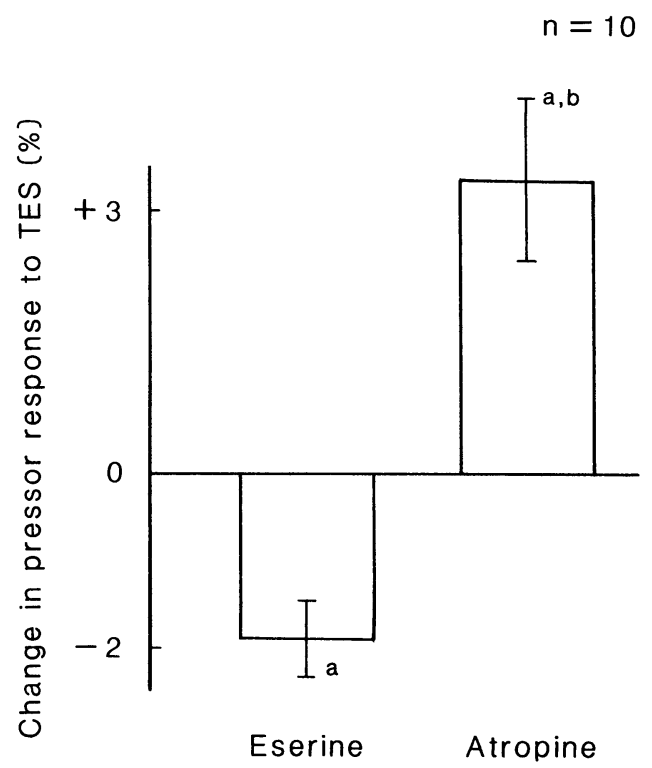

Fig. 1. Modification by physotigmine (eserine; $10^{-7} \mathrm{M}$ ) and atropine $\left(10^{-6} \mathrm{M}\right)$ of the pressor response to transmural electrical stimulation (TES, $20 \mathrm{~Hz}$ for $10 \mathrm{~s}$ ) in perfused dog mesenteric artery segments without the endothelium $(E(-), \mathrm{n}=10)$. Stimulation-induced increases in the perfusion pressure before application of physostigmine are expressed as zero; the mean absolute value was $40.4 \pm 8.6$ $\mathrm{mmHg}$. Significantly different from zero, ${ }^{a} \mathrm{p}<0.05$; Significantly different from eserine, ${ }^{b} \mathrm{p}<0.01$. Vertical bars represent SEM. 


\section{PERFUSED DOG MESENTERIC ARTERY (E-)}

- Transmural stimulation, $20 \mathrm{~Hz}$

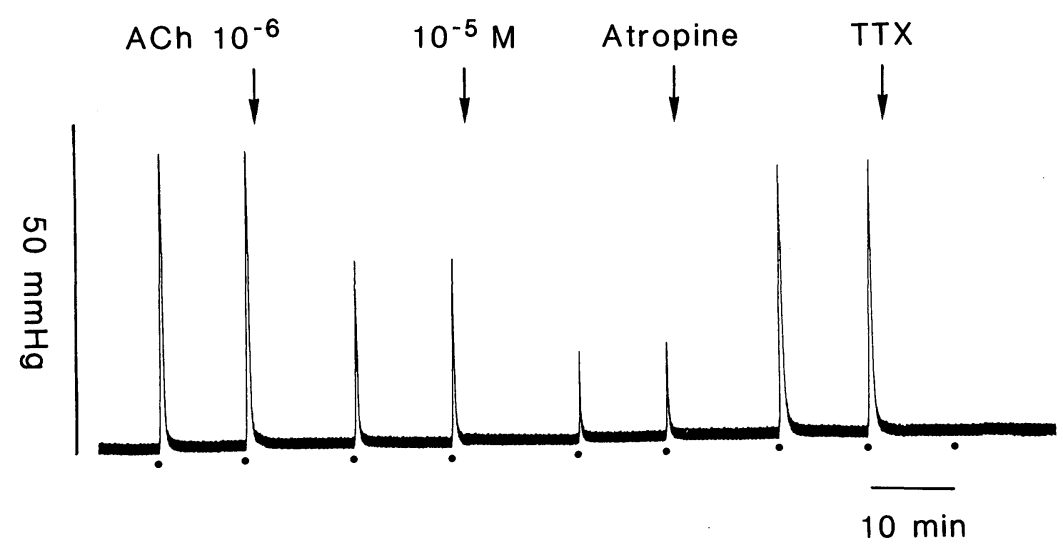

Fig. 2. Typical recording of the response to transmural electrical stimulation $(20 \mathrm{~Hz}$ for $10 \mathrm{~s})$ of a perfused mesenteric artery segment without the endothelium $(E(-))$ before and after treatment with $A C h\left(10^{-6}\right.$ and $\left.10^{-5} \mathrm{M}\right)$ and atropine $\left(10^{-6}\right.$ $M)$. Drugs were cumulatively applied directly to the organ bath. Each dot under the tracing represents the application of electrical stimulation. $T T X=3 \times 10^{-7} M$ tetrodotoxin.

PERFUSED DOG MESENTERIC ARTERY (E-)

- Transmural stimulation, $20 \mathrm{~Hz}$

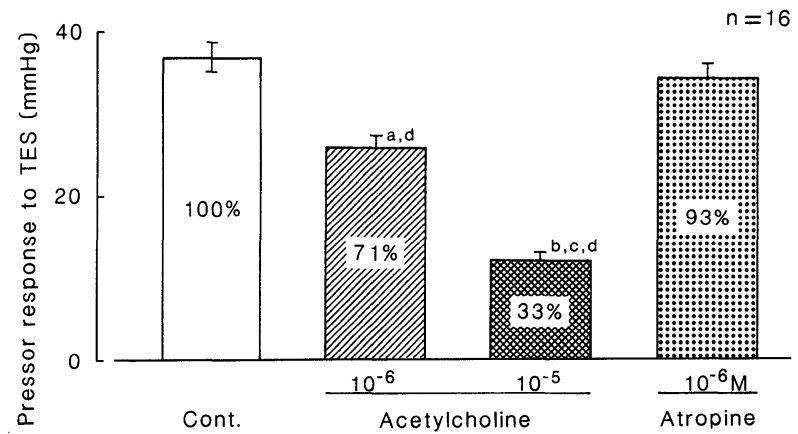

Fig. 3. Effects of ACh $\left(10^{-6}\right.$ and $\left.10^{-5} \mathrm{M}\right)$ on the pressor response to transmural electrical stimulation (TES, $20 \mathrm{~Hz}$ for $10 \mathrm{~s})$ and modification by atropine $\left(10^{-6} \mathrm{M}\right)$ of the inhibition due to ACh in perfused dog mesenteric artery segments without the endothelium $(E(-), \mathrm{n}=16)$. Stimulationinduced increases in the perfusion pressure before application of ACh are expressed as control. Significantly different from control, ${ }^{a} \mathrm{p}<0.01,{ }^{b} \mathrm{p}<0.001$; significantly different from acetylcholine $\left(10^{-6} \mathrm{M}\right),{ }^{c} \mathrm{p}<0.01$; significantly different from atropine, ${ }^{d} \mathrm{p}<0.01$. Vertical bars represent $S E M$.

\section{Statistical Analysis and Drugs Used}

The results shown in the text, table, and figures are expressed as mean values \pm SEM. Statistical analyses were made with Student's paired and unpaired $t$ test or Tukey's method after one-way analysis of variance. The drugs used were acetylcholine chloride (ACh, Daiichi Pharmaceutical Co., Tokyo, Japan), atropine sulphate (Tanabe Pharmaceutical Co., Osaka, Japan), physostigmine sulphate (Sigma, St.
PERFUSED DOG MESENTERIC ARTERY (E-)

- Transmural stimulation, $20 \mathrm{~Hz}$

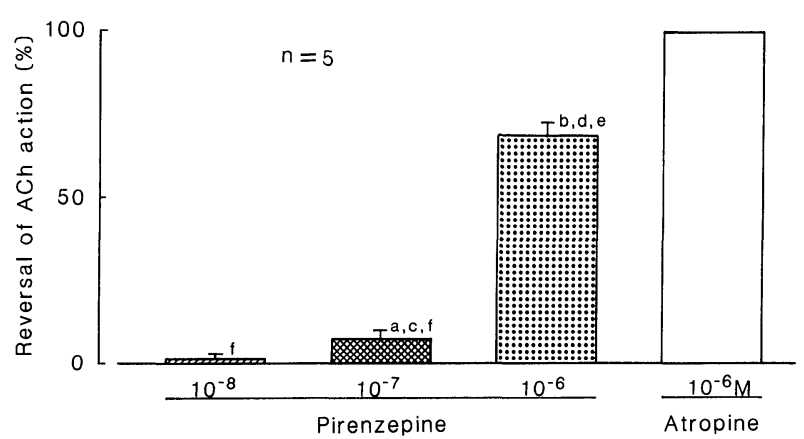

Fig. 4. Modification by pirenzepine $\left(10^{-8}, 10^{-7}\right.$ and $\left.10^{-6} \mathrm{M}\right)$ and atropine $\left(10^{-6} \mathrm{M}\right)$ of the inhibitory effect of ACh $\left(10^{-5} \mathrm{M}\right)$ on the pressor response induced by transmural stimulation at $20 \mathrm{~Hz}$ of perfused dog mesenteric artery segments without the endothelium $(E(-), \mathrm{n}=5)$. Stimulation-induced increases in the perfusion pressure after application of atropine $\left(10^{-6} \mathrm{M}\right)$ are expressed as $100 \%$; the mean absolute value was $37.5 \pm 5.8 \mathrm{mmHg}$. Significantly different from zero, ${ }^{a} \mathrm{p}<0.05,{ }^{b} \mathrm{p}<0.01$; significantly different from pirenzepine $\left(10^{-8} \mathrm{M}\right),{ }^{c} \mathrm{p}<0.05$, ${ }^{d} \mathrm{p}<0.01$; significantly different from atropine, ${ }^{e} \mathrm{p}<0.01$, $f_{\mathrm{p}}<0.001$. Vertical bars represent $S E M$.

Louis, MO, USA), pirenzepine, AF-DX 116, 4DAMP, $\left[{ }^{3} \mathrm{H}\right]$ norepinephrine (NEN Research Products, DE, USA), prazosin hydrochloride (Wako Pure Chemical Industries Ltd., Osaka, Japan), tetrodotoxin, and norepinephrine hydrochloride (Sankyo Co., Tokyo). 


\section{PERFUSED DOG MESENTERIC ARTERY (E-) - Transmural stimulation, 20Hz}

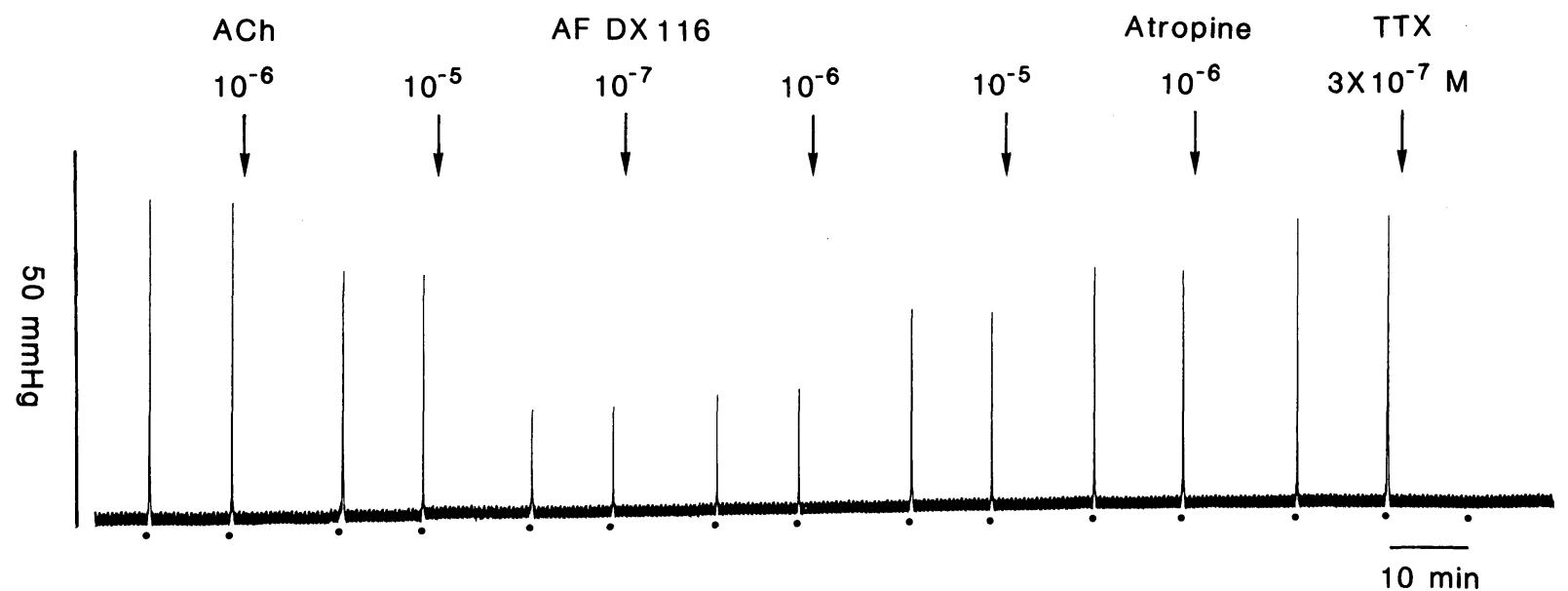

Fig. 5. Typical recording of the response to transmural electrical stimulation $(20 \mathrm{~Hz}$ for $10 \mathrm{~s})$ of a perfused mesenteric artery segment without the endothelium (E(-)) before and after treatment with $A C h\left(10^{-6}\right.$ and $\left.10^{-5} \mathrm{M}\right)$ and $\mathrm{AF}-\mathrm{DX} 116$ $\left(10^{-7}, 10^{-6}\right.$ and $\left.10^{-5} \mathrm{M}\right)$, and atropine. Drugs were cumulatively added directly to the organ bath. Each dot under the tracing represents the application of electrical stimulation. TTX $=3 \times 10^{-7} \mathrm{M}$ tetrodotoxin.

PERFUSED DOG MESENTERIC ARTERY (E-)

- Transmural stimulation, $20 \mathrm{~Hz}$

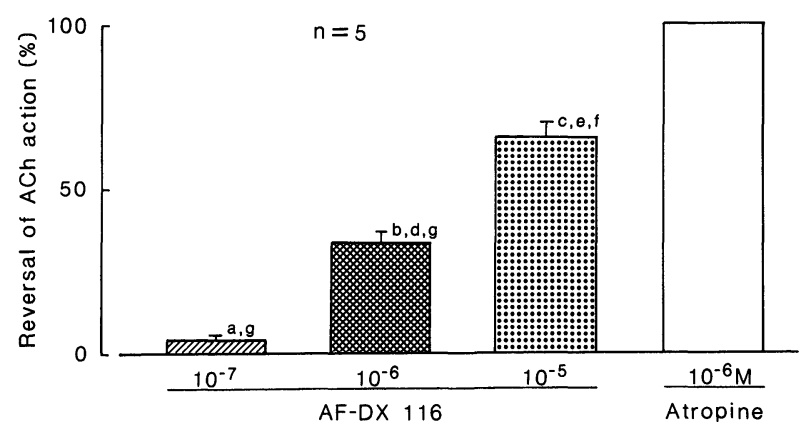

Fig. 6. Modification by $A F-D X 116\left(10^{-7}, 10^{-6}\right.$ and $\left.10^{-5} \mathrm{M}\right)$ and atropine $\left(10^{-6} \mathrm{M}\right)$ of the inhibitory effect of ACh $\left(10^{-5} \mathrm{M}\right)$ on the pressor response induced by transmural stimulation at $20 \mathrm{~Hz}$ of perfused dog mesenteric artery segments without the endothelium $(E(-), \mathrm{n}=5)$. Stimulation-induced increases in the perfusion pressure after application of atropine $\left(10^{-6} \mathrm{M}\right)$ are expressed as $100 \%$; the mean absolute value was $36.9 \pm 4.7 \mathrm{mmHg}$, Significantly different from zero, ${ }^{a} \mathrm{p}<0.05,{ }^{b} \mathrm{p}<0.01,{ }^{c} \mathrm{p}<$ 0.001 ; significantly different from $A F-D X 116\left(10^{-7} \mathrm{M}\right)$, ${ }^{d} \mathrm{p}<0.01,{ }^{e} \mathrm{p}<0.001 ;$ significantly different from atropine, $f_{\mathrm{p}}<0.01,{ }_{\mathrm{p}}<0.001$. Vertical bars represent $S E M$.
PERFUSED DOG MESENTERIC ARTERY (E-)

- Transmural stimulation, $20 \mathrm{~Hz}$

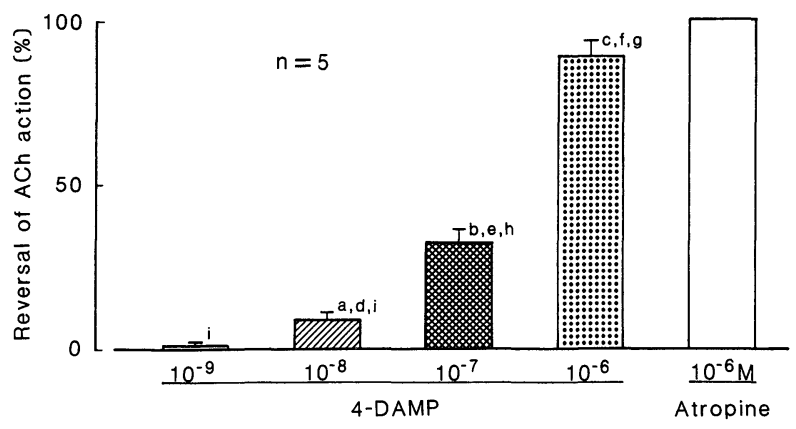

Fig. 7. Modification by 4-DAMP $\left(10^{-9}, 10^{-8}, 10^{-7}\right.$ and $\left.10^{-6} \mathrm{M}\right)$ and atropine $\left(10^{-6} \mathrm{M}\right)$ of the inhibitory effect of ACh $\left(10^{-5} \mathrm{M}\right)$ on the pressor response induced by transmural stimulation at $20 \mathrm{~Hz}$ of perfused dog mesenteric artery segments without the endothelium $(E(-), \mathrm{n}=5)$. Stimulation-induced increases in the perfusion pressure after application of atropine $\left(10^{-6} \mathrm{M}\right)$ are expressed as $100 \%$; the mean absolute value was $38.0 \pm 6.1 \mathrm{mmHg}$. Significantly different from zero, ${ }^{a} \mathrm{p}<0.05,{ }^{b} \mathrm{p}<0.01,{ }^{c} \mathrm{p}<$ 0.001 ; significantly different from 4-DAMP $\left(10^{-9} M\right)$, $d_{\mathrm{p}}<0.05,{ }^{e} \mathrm{p}<0.01,{ }_{\mathrm{p}}<0.001 ;$ significantly different from atropine, ${ }^{g} \mathrm{p}<0.05,{ }^{h} \mathrm{p}<0.01,{ }^{i} \mathrm{p}<0.001$. Vertical bars represent $S E M$. 
Table 1. The Ratio of ${ }^{3} \mathrm{H}-$ Overflow Evoked by Transmural Electrical Stimulation in the Absence and Presence of ACh

\begin{tabular}{lccc}
\hline & $N$ & $\mathrm{~S}_{4} / \mathrm{S}_{3}$ & $\mathrm{~S}_{5} / \mathrm{S}_{3}$ \\
\hline Control & 4 & $1.00 \pm 0.01$ & $0.98 \pm 0.01$ \\
Acetylcholine $\left(10^{-6} \mathrm{M}\right)$ & 4 & $0.50 \pm 0.03^{\mathrm{a}}$ & $0.57 \pm 0.07 \mathrm{a}$ \\
\hline
\end{tabular}

$N$, number of preparations used. Significantly different from controls, ${ }^{\mathrm{a}} p<0.001$.

The strip was treated for $12 \mathrm{~min}$ with $10^{-6} \mathrm{M} \mathrm{ACh}$ before the application of transmural electrical stimulation $\left(\mathrm{S}_{4}\right)$.

\section{Results}

Effect of Acetylcholine on the Response to Adrenergic Nerve Stimulation in Perfused Segments In dog mesenteric artery segments perfused at a rate of $1 \mathrm{ml} / \mathrm{min}$, transmural electrical stimulation $(5,10,20$, and $30 \mathrm{~Hz}$ for $40,20,10$, and 7 , respectively) produced a frequency-related increase in the perfusion pressure; the mean values were $3.6 \pm 0.6$, $20.4 \pm 1.7,37.2 \pm 3.1$, and $63.8 \pm 5.2 \mathrm{mmHg}(n=5)$, respectively. At a frequency of $20 \mathrm{~Hz}$ applied at an interval of 10 to $15 \mathrm{~min}$, the pressor response was consistent and reproducible; therefore, the effect of various agents on the response to this frequency of stimulation was evaluated. The pressor response was abolished by treatment with prazosin $\left(10^{-5} \mathrm{M}\right)$ or tetrodotoxin $\left(3 \times 10^{-7} \mathrm{M}\right)$, suggesting the involvement of norepinephrine released by activation of perivascular adrenergic nerves.

Physostigmine $\left(10^{-7} \mathrm{M}\right)$ slightly but significantly inhibited the pressor response to the transmural electrical stimulation. The inhibition was reversed to a potentiation by the addition of atropine $\left(10^{-6}\right.$ M) (Fig. 1).

ACh $\left(10^{-6}\right.$ and $\left.10^{-5} \mathrm{M}\right)$ did not alter the perfusion pressure in endothelium-denuded arterial segments, but significantly inhibited the pressor response to the transmural electrical stimulation dosedependently (Fig. 2). The inhibition was almost completely reversed by the addition of atropine $\left(10^{-6} \mathrm{M}\right)$. The quantitative data are summarized in Fig. 3.

Modifications by selective antagonists of $\mathbf{M}_{1}, \mathbf{M}_{2}$ and $\mathrm{M}_{3}$ muscarinic receptor subtypes (pirenzepine, AF-DX 116, and 4-DAMP, respectively) of the inhibitory effect of $\mathrm{ACh}$ on the pressor response to electrical nerve stimulation were investigated. The inhibition was not significantly affected by $10^{-8} \mathrm{M}$ pirenzepine but was reversed at $10^{-7}$ and $10^{-6} \mathrm{M}$ dose-dependently (Fig. 4). AF-DX 116 in concentrations from $10^{-7}$ to $10^{-5} \mathrm{M}$ significantly reversed the inhibition by $\mathrm{ACh}$ of the pressor response in a dose-dependent manner (Fig. 5). The quantitative data are summarized in Fig. 6. The inhibitory effect of $\mathrm{ACh}$ on the pressor response was not altered by $10^{-9} \mathrm{M}$ 4-DAMP, but was antagonized at $10^{-8} \mathrm{M}$ or higher (Fig. 7).

Effect of ACh on the Response to Norepinephrine in Perfused Artery Segments and Arterial Strips

The addition of norepinephrine $\left(7 \times 10^{-6}\right.$ to $8 \times$ $\left.10^{-6} \mathrm{M}\right)$ produced a sustained increase, averaging $21.3 \pm 0.9 \mathrm{mmHg}$, in the pressure of perfused mesenteric artery segments denuded of endothelium $(n=3)$. The sustained level of pressure was not influenced by the addition of ACh $\left(10^{-6}\right.$ and $10^{-5}$ $\mathrm{M})$, but was lowered by beraprost $\left(10^{-7} \mathrm{M}, 16.2 \pm\right.$ $0.7 \mathrm{mmHg}, n=3$ ), a stable analog of $\mathrm{PGI}_{2}$. In arterial strips, contractions elicited by exogenous norepinephrine were not significantly reduced by treatment with $\mathrm{ACh}$; the mean values of contractions induced by $5 \times 10^{-7} \mathrm{M}$ norepinephrine were $15.7 \pm$ $3.2,14.8 \pm 2.5$, and $14.9 \pm 2.5 \%(n=5$, relative to contractions induced by $30 \mathrm{mM} \mathrm{K}^{+}$) in control strips and those treated with $10^{-6}$ and $10^{-5} \mathrm{M}$ $\mathrm{ACh}$, respectively, and the values at $2 \times 10^{-6} \mathrm{M}$ norepinephrine were $90.6 \pm 8.8,89.7 \pm 9.1$, and 92.8 $\pm 8.8 \%(n=5)$, respectively.

Effect of ACh on ${ }^{3} \mathrm{H}$-Overflow Elicited by Transmural Electrical Stimulation

In order to determine the prejunctional action of $\mathrm{ACh}$, the modulation by $\mathrm{ACh}$ of the release of $\left[{ }^{3} \mathrm{H}\right]$ norepinephrine evoked by perivascular nerve stimulation was studied. Transmural electrical stimulation at a frequency of $5 \mathrm{~Hz}$ for $3 \mathrm{~min}$ at intervals of $18 \mathrm{~min}$ increased ${ }^{3} \mathrm{H}$-overflow from superfused mesenteric arterial strips, which had been incubated for $60 \mathrm{~min}$ in $\left[{ }^{3} \mathrm{H}\right]$ norepinephrine and stabilized for 126 min during superfusion with normal bathing media. ACh was applied just after the third stimulation $\left(S_{3}\right)$. The ratios of the overflow, $S_{4} / S_{3}$ and $\mathrm{S}_{5} / \mathrm{S}_{3}$, in the control series were $1.00 \pm 0.01$ and 0.98 $\pm 0.01(n=4)$, respectively, and were significantly decreased by treatment with $10^{-6} \mathrm{M}$ ACh (Table 1).

\section{Discussion}

Transmural electrical stimulation $(5-30 \mathrm{~Hz})$ produced a frequency-related pressor response in isolated perfused dog mesenteric artery segments that was abolished by treatment with prazosin and tetrodotoxin. Therefore, the observed response is expected to derive mainly from norepinephrine released from electrically stimulated adrenergic nerve endings. The present study showed that physostigmine, an acetylcholinesterase inhibitor, slightly but significantly inhibited the pressor response to the electrical nerve stimulation, and atropine potentiated the response, suggesting the involvement of endogenous $\mathrm{ACh}$ in inhibition of the neurally induced vasoconstriction. The neurogenic pressor response was also attenuated by exogenous $\mathrm{ACh}$, the inhibition being reversed by atropine. ACh did not decrease the perfusion pressure raised by norepinephrine in endothelium-denuded arterial seg- 
ments nor the contractile response to norepinephrine in arterial strips denuded of the endothelium. In addition, ACh decreased the ${ }^{3} \mathrm{H}$ overflow evoked by nerve stimulation in superfused mesenteric arterial strips previously soaked in ${ }^{3} \mathrm{H}$ norepinephrine-containing media. Therefore, it is concluded that the inhibitory effect of $\mathrm{ACh}$ on the pressor response to nerve stimulation is associated with an inhibition of the release of norepinephrine from nerve endings, possibly by activation of prejunctional muscarinic receptors. Prejunctional modulation by exogenous $\mathrm{ACh}$ of the response to adrenergic nerve stimulation has also been reported in canine (16) and human (17) saphenous veins and guinea-pig carotid arteries (18), whereas only limited information is available concerning the inhibitory effect of endogenous $\mathrm{ACh}$ on the response to efferent nerve stimulation (19). Under the experimental conditions used in the present study, the inhibition by neurogenic $\mathrm{ACh}$ was appreciably less than that elicited by exogenous ACh, possibly because the amount released from the nerve by the stimulation frequency applied is not sufficient to elicit evident attenuation.

There are three different muscarinic receptor subtypes, $\mathbf{M}_{1}, \mathbf{M}_{2}$, and $\mathbf{M}_{3}(5,7)$. The present study revealed that the ACh-induced inhibition of the pressor response to adrenergic nerve stimulation was not altered by the addition of pirenzepine at $10^{-8}$ $\mathrm{M}$, a concentration sufficient to selectively inhibit $\mathrm{M}_{1}$ receptor subtype $(16,20)$ or by $10^{-9} \mathrm{M} 4-$ DAMP, which is enough to selectively block $\mathrm{M}_{3}$ subtype (21-23). It has been reported that $\mathrm{pA}_{2}$ values for AF-DX 116 at $\mathrm{M}_{2}$ receptors range from 6.8 to $7.4(6,11,12)$. The present study demonstrated that the inhibition by ACh of the pressor response to adrenergic nerve stimulation was significantly reversed by AF-DX 116 in concentrations of $10^{-7} \mathrm{M}$ or higher, suggesting that the prejunctional muscarinic receptor subtype involved is $\mathbf{M}_{2}$. Similar findings have also been reported in cat (24) and bovine (19) cerebral and guinea-pig carotid arteries (18) and canine saphenous veins (16). On the other hand, involvement of prejunctional $\mathrm{M}_{3}$ receptor subtype in the inhibition (19) and of $\mathrm{M}_{1}$ receptor subtype in the facilitation of norepinephrine release (18) has also been reported.

In conclusion, evidence obtained from the present study indicates that the inhibitory effect of endogenous and exogenous $\mathrm{ACh}$ on the pressor response to nerve stimulation is exerted via an inhibition of norepinephrine release from nerve endings. The prejunctional muscarinic receptor responsible for inhibiting the transmitter release is supposed to be of the $\mathrm{M}_{2}$ subtype.

\section{References}

1. Brayden JE, Large WA: Electrophysiological analysis of neurogenic vasodilatation in the isolated lingual artery of the rabbit. BrJ Pharmacol 1986; 89: 163171.

2. Vanhoutte PM, Lorenz R, Tyce GM: Inhibition of norepinephrine- ${ }^{-3} \mathrm{H}$ release from sympathetic nerve endings in veins by acetylcholine. J Pharmacol Exp Ther 1973; 185: 386-394.

3. Vanhoutte PM: Inhibition by acetylcholine of adrenergic neurotransmission in vascular smooth muscle. Circ Res 1974; 34: 317-326.

4. Toda $\mathbf{N}$, Inoue $\mathrm{S}$, Okunishi $\mathrm{H}$, Okamura $\mathrm{T}$ : Intraand extraluminally-applied acetylcholine on the vascular tone or the response to transmural stimulation in dog isolated mesenteric arteries. Naunyn Schmiedebergs Arch Pharmacol 1990; 341: 30-36.

5. Hammer R, Giachetti A: Muscarinic receptor subtypes: $M_{1}$ and $M_{2}$ biochemical and functional characterization. Life Sci 1982; 31: 2991-2998.

6. Giachetti A, Micheletti R, Montagna E: Cardioselective profile of AF-DX 116, a muscarine $\mathrm{M}_{2}$ receptor antagonist. Life Sci 1986; 38: 1663-1672.

7. Doods HN, Mathy MJ, Davidesko D, Charldorp KJV, Jonge AD, Zwieten PAV: Selectivity of muscarinic antagonists in radioligand and in vivo experiments for the putative $\mathrm{M}_{1}, \mathrm{M}_{2}$ and $\mathrm{M}_{3}$ receptors. $J$ Pharmacol Exp Ther 1987; 242: 257-262.

8. Barlow RB, Shepherd MK: A search for selective antagonists at $\mathrm{M}_{2}$ muscarinic receptors. Eur J Pharmacol 1985; 85: 427-435.

9. Fude H, Meiser C, Wormstall H, Muscholl E: The effects of several muscarinic antagonists on pre- and postsynaptic receptors in the isolated rabbit heart. Naunyn Schmiedebergs Arch Pharmacol 1981; 316: 31-37.

10. Habermeier-Muth A, Altes U, Forsyth KM, Muscholl E: A presynaptic excitatory $M_{1}$ muscarinic receptor at postganglionic cardiac noradrenergic nerve fibres that is activated by endogenous acetylcholine. Naunyn Schmiedebergs Arch Pharmacol 1990; 342: 483-489.

11. Costa M, Majewski H: Evidence for facilitatory and inhibitory muscarinic receptors on postganglionic sympathetic nerves in mouse isolated atria. $\mathrm{Br} J$ Pharmacol 1991; 102: 855-860.

12. Bognar I, Baumann $\mathrm{B}$, Dammann $\mathrm{F}$, et al: $\mathrm{M}_{2}$ muscarinic receptors on the iris sphincter muscle differ from those on iris noradrenergic nerves. Eur J Pharmacol 1989; 163: 263-274.

13. Eltze $\mathrm{M}$ : Muscarinic $\mathbf{M}_{1}$ - and $\mathbf{M}_{2}$-receptors mediating opposite effects on neuromuscular transmission in rabbit vas deferens. Eur J Pharmacol 1988; 151: 205-221.

14. Toda N, Miyazaki M: Responses of isolated dog cerebral and peripheral arteries to prostaglandins after application of aspirin and polyphloretin phosphate. Stroke 1978; 9: 490-498.

15. Toda N, Inoue S, Okunishi H: Prejunctional alpha adrenoceptor and angiotensin receptor function in isolated human, monkey and dog arteries. $J$ Pharmacol Exp Ther 1988; 246: 662-666.

16. O'Rourke ST, Vanhoutte PM: Subtypes of muscarinic receptors on adrenergic nerves and vascular smooth muscle of the canine saphenous vein. $J$ Pharmacol Exp Ther 1987; 241: 64-67.

17. Rorie DK, Rusch NJ, Shepherd JT, Vanhoutte PM, Tyce GM: Prejunctional inhibition of norepinephrine release caused by acetylcholine in the human saphenous vein. Circ Res 1981; 49: 337-341.

18. Casado MA, Sevilla MA, Alonso MJ, Marin J, Salaices M: Muscarinic receptors involved in modulation of norepinephrine release and vasodilatation in guinea pig carotid arteries. J Pharmacol Exp Ther 1994; 271: 1638-1646.

19. Ferrer M, Galván R, Marín J, Balfagón G: Presynaptic muscarinic receptor subtypes involved in the 
inhibition of acetylcholine and noradrenaline release in bovine cerebral arteries. Naunyn Schmiedebergs Arch Pharmacol 1992; 345: 619-626.

20. Brown DA, Forward A, Marsh S: Antagonist discrimination between ganglionic and ileal muscarinic receptors. Br J Pharmacol 1980; 71: 362-364.

21. Roffel AF, Elzinga CRS, Van Amsterdam RGM, De Zeeuw RA, Zaagsma J: Muscarinic $\mathrm{M}_{2}$ receptors in bovine tracheal smooth muscle: discrepancies between binding and function. Eur J Pharmacol 1988; 153: $73-82$.

22. Van Charldorp KJ, Van Zwieten PA: Comparison of the muscarinic receptors in the coronary artery, cere- bral artery and atrium of the pig. Naunyn Schmiedebergs Arch Pharmacol 1989; 339: 403-408.

23. Fuder H, Schopf J, Unckell J, et al: Different muscarine receptors mediate the prejunctional inhibition of $\left[{ }^{3} \mathrm{H}\right]$-noradrenaline release in rat or guinea-pig iris and the contraction of the rabbit iris sphincter muscle. Naunyn Schmiedebergs Arch Pharmacol 1989 340: 597-604.

24. Alonso MJ, Arribas S, Marín J, Balfagón G, Salaices $\mathrm{M}$ : Presynaptic $\mathrm{M}_{2}$-muscarinic receptors on noradrenergic nerve endings and endothelium-derived $\mathbf{M}_{3}$ receptors in cat cerebral arteries. Brain Res 1991; 567: 76-82. 